\title{
Assessing Off-site Readiness in construction organisations: Cases from India.
}

\section{Abstract}

\section{Purpose}

This paper intends to present factors affecting the Indian construction organisations in adopting Off-Site Construction (OSC) methods.

\section{Design/Methodology/Approach}

An existing readiness maturity model has been used to assess three large organisations in different parts of India. A case study methodology has been adopted in this paper to highlight critical issues in OSC adoption in India.

\section{Findings}

This paper presents three case studies and concludes the Indian construction sectors readiness to adopt the OSC methods. Through the case studies, different issues related to the adoption of OSC have been identified and highlighted for the Indian construction sector. Although the three companies are large, there are several Small and Medium-sized Enterprises' (SME) operating in India's construction sector, and future research shall be needed to review these SMEs.

\section{Originality/Value}

Through the three case studies, several factors related to the implementation of OSC methods have been identified and highlighted within the Indian construction sector. Although the model has been applied to the Indian construction sector, it can easily be modified to fit into other areas and similar dynamics and business conditions.

\section{Practical Implications}

The proposed OSC readiness maturity model guides construction practitioners in India through a structured process to assess their OSC readiness in the market. This assessment enables them to evaluate and benchmark their processes through the strategic and operational phases. This research will add to the existing knowledge of OSC in India by mapping issues relevant to India's construction industry. The research has provided background on the status of OSC, the drivers and barriers affecting the implementation of Off-site Construction techniques in the Indian construction industry.

\section{Limitations:}

This research study is broadly focused on developing and assessing an off-site construction readiness framework for Indian construction organisations. The research scope and the population for data collection are limited to Large construction organisations in India only.

\section{Keywords}

Off-site Construction, OSC, Construction industry, Housing, Modular Construction, Indian construction. 


\section{Introduction}

The construction industry has often been criticised for its slow adoption of emerging technologies (Yang, O'Connor and Chen, 2007; Ahuja et al., 2009; Herr and Fischer, 2019), laggings behind other industries in taking advantage of new technologies and innovative practices (Nadim and Goulding, 2011; Gan et al., 2018; Navaratnam et al., 2019). over recent years, this trend has changed. Globally there is a growing awareness of the use of Off-Site Construction (OSC) techniques and has received broader acceptance in other practising nations; however, it has yet to gain momentum in India, with the country only beginning to consider to use of OSC practices in recent years (Arif et al., 2012; Bendi et al., 2020a; Bendi et al., 2020b). Innovation in the construction industry has often been observed as slow-moving; in India's case, the technological 'conservatism' (Tiwari, 2001; Luthra et al., 2016) is further hindering the shift towards new methods and innovative practices.

In India, the construction industry is gradually becoming sustainable, with the past decade witnessing significant growth in the green footprint (Vyas and Jha, 2016). Sustainability has been prioritised among the top issues in the sustainable development agenda 2030 and the research and innovation of the construction industry (Arif et al., 2010; Scheyvens et al., 2016; Mensah, 2019). However, the increasing need for housing and infrastructure in India is challenging any sustainable performance. (Shrivastava and Chini, 2011). Additionally, several factors have impacted on the construction industry in the past decade (Arif and Egbu, 2010). India's industry is expected to facilitate the growing population and increase the need for infrastructure (Cheng, 2016). On the other hand, it is facing significant challenges in achieving quality and speed in construction. Low quality, delays in completion, high demand and lack of construction project management skills are challenging growth and consistency in the industry.

In recent years, many Indian construction organisations are responding to the increasing interest in OSC, but lack of awareness and confusion has discouraged intensive implementation (Wuni et al., 2020). Organisations are also sceptical about their capabilities of integrating OSC practices into their construction activities (El-Abidi et al., 2019) and they currently lack adequate resources to facilitate and satisfy market needs if extensive off-site procedures are implemented in the industry (Goodier and Gibb, 2007; Edialeyoung et al., 2020). As such, this research paper intends to fill this gap in the literature and aims to assess and validate an OSC readiness maturity model in three different Indian construction organisations. OSC readiness can be defined as 'a measure of the degree to which the organisation may be ready, prepared, or willing to obtain benefits which arise from the OSC practices. The OSC readiness maturity model aims to investigate 'how ready the organisation is to adopt OSC techniques in their current practice?' Thus, the OSC readiness maturity model investigates the extent to which any organisation is ready to adopt OSC technologies in various construction organisations.

This paper presents three case studies of construction companies in India detailing practices which can help the adoption of OSC. The following section includes a literature review and discusses a framework to assess the processes that impact the OSC adoption and methodology. The paper then discusses three case studies from construction consultancies in India. It is 
followed by a section that analyses the cases and presents some best practices. The last section summarised the findings and concluding remarks of the cases.

\section{Background and Literature Review}

OSC attained a considerable focus in major recommendations to achieve greater productivity and pace in construction projects. Many researchers have foreseen off-site construction as the future of the construction industry. Industry advisors and experts have repeatedly recommended that the industry use more off-site and standardisation to increase quality and reduce cost and time (Badir, Kadir and Hashim, 2002; Goodier and Gibb, 2007; Pan, Gibb and Dainty, 2007; Tam et al., 2007; Blismas and Wakefield, 2009; Arif and Egbu, 2010). Goulding et al., (2012b) examined the challenges and drivers for off-site uptake globally based on the literature and questionnaire surveys. Researchers have also highlighted the need for further investigations on the attributes affecting people, process and technology in the OSC context. Recent studies in India reported a lack of international exposure to construction activities, especially in large scale projects and physical infrastructure development (Jha and Devaya, 2008; Arif et al., 2010). Other points include the dominance of traditional practices that are highly labour-intensive and uncertainty in cost and time schedules (Tiwari, 2001; Auti and Skitmore, 2008). Therefore, addressing the high demand for housing and infrastructure facilities, sustainable built environment, global knowledge transfer and exchange into the Indian construction industry are imperative.

The literature review highlighted the importance and advantages of using OSC techniques, but as discussed, the current level of OSC uptake is low in India; however, it is gradually spreading into the industry. Work was initiated regarding the Indian scenario in recent years (Smith and Narayanamurthy, 2008; Arif et al., 2012), but there is no comprehensive study on the status of OSC in India. Additionally, there is no evidence of successful implementation of OSC in the Indian context in the literature. In the highly competitive construction industry, the top organisations continuously search for proven technologies for a competitive advantage (Yang et al., 2007), this, however, has been changing in the last few years and the organisations have been focussing more on the innovative technologies to gain a competitive edge. Lack of awareness and information regarding new technologies' benefits discourages industry stakeholders from taking up new practices (Yu, Wu and Lien, 2008). Hence, there is a need for tangible evidence of the advantages of using different OSC techniques levels. Organisations quickly identified the potential benefits of efficient off-site practices in many countries (Haas and Fagerlund, 2002; Azman et al., 2012). Researchers from other practising nations such as the UK, USA, Australia, China and Malaysia have documented the experiences and lessons regarding OSC in the literature; but in the developing countries, there is a strong need for tangible research (Nadim and Goulding, 2011; Goulding, Nadim, et al., 2012).

Researchers have extensively studied OSC in various developed nations, and some of them demonstrated the role of strategy in implementing it. Gibb (2001) revealed that project strategy is essential to changing the project process from 'traditional construction' to 'manufacturing and 
installation' (Durdyev and Ismail, 2019). Similarly, Egbu (2004), Naoum and Egbu (2016) and Attar et al. (2018) believed that organisational strategies for innovation are "path-dependent". According to Egbu (2004), organisations' innovation strategies, are strongly constrained by their current position and core competencies, as well as the specific opportunities open to them in the future. Aldridge et al., (2001) clarified that lack of formal measurement procedures or strategies in the context of off-site is hindering the extensive usage of OSC.

While some studies demonstrated the importance of strategies, Goulding et al., 2012 highlighted the lack of feasible business process models for promoting OSC in a meaningful way. Blismas et al. (2006) revealed that evaluating the degree of industrialisation of a component or building system production in off-site construction is inadequate in the construction industry. They also highlighted the need for the holistic and systematic assessments of the applicability and overall benefit of these solutions. Further, Smith and Narayanamurthy (2008) stressed the need to investigate an appropriate prefabricated building system to fulfil the present context's housing shortage. Kamar et al. (2009) highlighted the need for kick-starting projects to create more opportunities and spilling out the effect on the entire industry. It is time to rethink how construction projects could be conceived, planned, and executed to achieve maximum benefits through OSC practices. As discussed above, currently, there is minimal available OSC research in India regarding the process level and selfassessment. Additionally, there is no comprehensive industry-wide study on the impacts of OSC usage in the construction industry. In recent years, many Indian construction organisations are responding to the increasing interest in OSC and manufacturing construction. Lack of awareness and confusion has discouraged any intensive implementation of OSC Organisations are sceptical about their capabilities of integrating OSC practices in their construction activities (Goodier and Gibb, 2005; Pan et al., 2007; Blismas and Wakefield, 2009; Zhai et al., 2014).

This research developed an off-site construction readiness framework for Indian construction organisations. According to Keupp and Gassmann (2013), it is essential to compare and test the existing knowledge/practices in an organisation before introducing any innovation. Therefore, the investigation and documentation of the current state and knowledge of OSC practices in India were undertaken. A derived OSC readiness framework assesses the maturity level of the construction organisation in India; this mechanism of an 'off-site construction readiness framework' has similarities with Capability Maturity Models (CMMs). According to Page et al. (2004), CMMs guide organisations on defining processes. They describe what activities must be performed to meet specific criteria. By exercising through the off-site readiness framework, the organisations would gain knowledge on OSC and know their capability for adopting OSC in construction projects. The model dictates the capacity of the organisation to implement OSC in certain construction activities. Thus, the organisation's maturity level and the characteristics, can be studied based on the results obtained from the OSC readiness model. In addition to the OSC readiness framework, the research proposes a strategy for extensive implementation of off-site practices in India. 


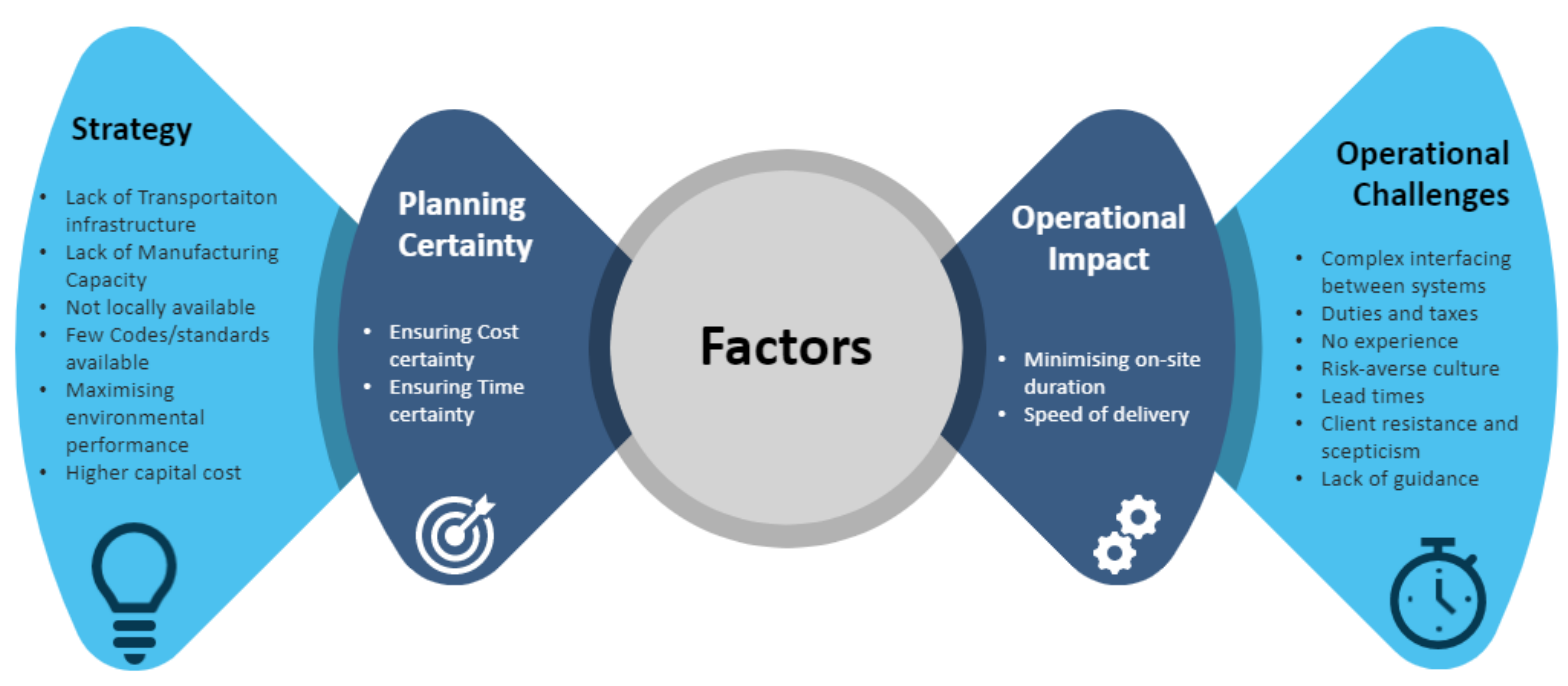

Figure 1 Factor Analysis Variables and Four Groups (Bendi et al., 2020)

Four key factors presented in Figure 1. illustrate possible trajectories for future uptake. However, Bendi et al. (2020) present these variables in isolation. Other work on OSC examined the crucial aspects of People, Process and Technology (Nadim and Goulding, 2010; Goulding et al., 2012) including OSC roadmaps (Goulding and Arif, 2013; Bowmaster and Rankin, 2019), Platform, Process and Product integration platforms (Blismas and Wakefield, 2008), OSC Future Landscapes (Oughton, 2016). Whilst all these attempts provide points for discussion and further development, the main challenge remains, how do organisations prepare themselves for OSC transition? At an organisational level, where OSC uptake occurs, this needs addressing; this is where the level of 'readiness' and organisational maturity is so important.

Level 1 (No Clear Application) presents organisations with issues they need to re-visit regarding their existing operations and any necessary restructuring to improve efficiency/readiness. Level 2 (Frequent Application, but Lack of Standard Practice) highlights the frequency of application lack of policy issues, including the need to significantly repeat and standardise processes in line with clear strategy/policy directions. Level 3 (Clear Established Practices and Procedures) focuses on the need to establish clear OSC policies. This includes a full evaluation of existing operations with clear project strategies to deliver best practice, recording experiences from previous projects and best in class provision offered by other companies and documenting lessons learned (as part of their organisational learning strategy). 
Table 1 Offsite Construction Readiness Maturity Model

\begin{tabular}{|c|c|c|c|}
\hline Factors & Level 1 & Level 2 & Level 3 \\
\hline & NO CLEAR APPLICATION & $\begin{array}{l}\text { FREQUENT APPLICATION. LACK } \\
\text { OF STANDARD PRACTICE }\end{array}$ & ESTABLISHED OPERATING PROCEDURE \\
\hline & $\begin{array}{l}\text { The organisation may / may not } \\
\text { practice the critical steps for effective } \\
\text { implementation of Offsite techniques. } \\
\text { Organisations at this level need to } \\
\text { revisit their existing operations and } \\
\text { restructure their team to improve } \\
\text { efficiency/readiness. }\end{array}$ & $\begin{array}{l}\text { This level represents the frequency of } \\
\text { application. At this level, the organisation } \\
\text { significantly repeats a series of critical } \\
\text { techniques. However, it will have scope for } \\
\text { improvement in processes and need to } \\
\text { define the standard practice. }\end{array}$ & $\begin{array}{l}\text { At this level, the organisation has clear standard practice } \\
\text { about Offsite Construction methods. It continually } \\
\text { reviews the existing operations and plans the project } \\
\text { strategies to increase efficiency—-the organisations at this } \\
\text { level, document best procedures through recording } \\
\text { experiences and lessons from the previous projects. }\end{array}$ \\
\hline \multicolumn{4}{|l|}{ F1. Operational challenges } \\
\hline $\begin{array}{l}\text { F1. 1. Complex interfacing between the } \\
\text { systems: How does the organisation respond to } \\
\text { the challenges in assembling individual } \\
\text { systems/products of a complex nature? }\end{array}$ & $\begin{array}{l}\text { Is the workforce aware of the } \\
\text { assembling techniques and interfacing } \\
\text { of different products? }\end{array}$ & $\begin{array}{l}\text { Does the organisation demonstrate how to } \\
\text { assemble new, complex structures before } \\
\text { erecting them onsite? }\end{array}$ & $\begin{array}{l}\text { Does the organisation expedite the learning curve from } \\
\text { one offsite project to another project, through integrating } \\
\text { training programs in the strategy? Also, does the } \\
\text { organisation prioritise capacity building in the policy? }\end{array}$ \\
\hline $\begin{array}{l}\text { F1.2. Duties and taxes: How does the } \\
\text { organisation consider the leviability of duties } \\
\text { and taxes on the Offsite products? }\end{array}$ & $\begin{array}{l}\text { Does the organisation identify the } \\
\text { potential challenges associated with } \\
\text { the duties and taxes on the Offsite } \\
\text { products? }\end{array}$ & $\begin{array}{l}\text { Does the material procurement strategy of } \\
\text { the organisation consider both imported } \\
\text { and domestic Offsite products? Also, does } \\
\text { the organisation maintain any records to } \\
\text { monitor the duties and taxes payable / } \\
\text { already paid? }\end{array}$ & $\begin{array}{l}\text { Does the organisation achieve optimal utilisation of } \\
\text { imported and domestic products? Does it always } \\
\text { prioritise the Offsite products entitled to incentives or } \\
\text { exemptions from the taxes? }\end{array}$ \\
\hline $\begin{array}{l}\text { F1.3. Level of experience in Offsite } \\
\text { construction: How many offsite projects have } \\
\text { been handled? What is the level of expertise of } \\
\text { the organisation? }\end{array}$ & $\begin{array}{l}\text { Are the design and project } \\
\text { development teams aware of the } \\
\text { techniques and methods involved in } \\
\text { offsite construction practices? }\end{array}$ & $\begin{array}{l}\text { Do all the senior management, project } \\
\text { teams, construction workforce have } \\
\text { significant experience in handling offsite } \\
\text { construction projects? }\end{array}$ & $\begin{array}{l}\text { Does the organisation maintain a structure with a } \\
\text { dedicated project team and workforce that are specialised } \\
\text { in offsite construction operations? }\end{array}$ \\
\hline $\begin{array}{l}\text { F1.4. Promoting the advantages of Offsite } \\
\text { Construction techniques: How does the } \\
\text { organisation handle the existing negative image } \\
\text { (Goodier \& Gibb, 2007; Arif } \text { et al., 2012) on } \\
\text { offsite construction methods? Does it promote } \\
\text { the advantages associated with the OSC } \\
\text { method? }\end{array}$ & $\begin{array}{l}\text { Does the organisation promote the } \\
\text { potential benefits from offsite } \\
\text { construction methods? Also, does the } \\
\text { organisation conduct any } \\
\text { enlightenment programs/one to one } \\
\text { session with the potential clients to } \\
\text { clarify their concerns? }\end{array}$ & $\begin{array}{l}\text { Does the organisation maintain a calendar } \\
\text { of awareness workshops? Also, does it } \\
\text { brief the potential clients about the nature } \\
\text { of work, application methods and } \\
\text { achievable benefits before starting the } \\
\text { project? }\end{array}$ & $\begin{array}{l}\text { Does the organisation extensively promote the benefits of } \\
\text { OSC products by showcasing successful projects, value } \\
\text { proposition and product samples? Also, does it include } \\
\text { the promotional activities in the strategy? }\end{array}$ \\
\hline
\end{tabular}


F1.5. Lead times: What is the capability of the organisation in avoiding delays caused by long lead times?

\section{F1.6. Client's resistance and scepticism: How} does the organisation address the resistance from clients?

\section{F1.7. Guidance and information: To what} extent, does the organisation support the field staff with guidance and information on offsite construction techniques?

\section{F2. Broad execution strategy}

F2.1. Transportation infrastructure: What are the plans and arrangements made by the organisation to address the problems raised due to the existing poor road and transportation network?

F2.2. Manufacturing facility: How does the organisation handle the volume of products and other resources required?

F2.3. Shortage in availability: How does the organisation overcome the shortage of OSC products due to lack of local manufacturers?

F2.4. Availability of codes/standards: The extent to which the organisation provide guidelines to the designers, operators and another construction workforce.
Does the organisation consult the manufacturers before planning all critical events in the project schedule?

Does the organisation explain to the client about the potential benefits of using OSC methods?

\section{Is the field workforce in the} organisation provided with training, technical manuals, and literature on new products? Also, is this accessible to the entire workforce?
Are all events planned according to the delivery schedules to avoid time lags

between the commencement and completion of the project?

Does the organisation assure client about the added advantages with precise estimates and documentation along with a detailed project plan?

\section{Does the organisation arrange workshops} and dedicated training from the manufacturers before implementing any new projects?

Is the organisation aware of the minimum requirements to transport materials used in offsite construction projects?

Does the organisation estimate the requirement/quantities and consult the manufacturing facility before starting construction?

Does the organisation address the encountered challenges in procuring OSC products?

Are there any written standards guidelines available to all the members in the project team?
If yes, does it critically evaluate the

existing road and transportation network

and customise their procurement strategy accordingly?

If yes, does the organisation complete the selection process at the early stage and place orders with effective planning?

Does the organisation supplement imported products with locally manufactured products?

Does the organisation strictly follow the standards throughout the design and construction stages?
Does the organisation closely work with manufacturers and all the supply chain involved in the projects? Also, does it collaborate with manufacturers and facilitate an in-house set up for greater control on-time schedules? Does the organisation involve the client in the vital decision-making process and clarify any concerns with clear evidence / past success stories? Also, does the organisation showcase successful projects and

communicate the client about the progress of critical events with detail documentation?

Does the organisation have dedicated resources

(instructor, technical team, library, training room,

facilities which enable audiovisual demonstration) for

training and guidance in office and onsite?

Does the organisation co-ordinate with the manufacturers at the initial stage and document route plan and schedules before placing the order (or) before starting the project?

Does the organisation evaluate the capacity of manufacturers to meet demand? Also, does the organisation enter into agreements with supply contracts?

Does the organisation comprise an in-house facility or collaboration with foreign manufacturers, to transfer and utilise their technology?

Does the organisation document the instructions before design and monitor the activities to ensure compliance with the standards? 


\begin{tabular}{|c|c|c|c|}
\hline $\begin{array}{l}\text { F2.5. Maximising environmental } \\
\text { performance in the life cycle: To examine the } \\
\text { strategies deployed by the organisation to } \\
\text { maximise the usage of sustainable products and } \\
\text { processes in various projects. }\end{array}$ & $\begin{array}{l}\text { Is the organisation aware of the } \\
\text { offsite products that are sustainable? } \\
\text { If yes, does it prioritise the usage of } \\
\text { sustainable products? }\end{array}$ & $\begin{array}{l}\text { Does the organisation decide to adopt } \\
\text { sustainable practices (selection of } \\
\text { sustainable products, minimising waste } \\
\text { during construction, etc.) at the beginning } \\
\text { of the project? }\end{array}$ & $\begin{array}{l}\text { Does the organisation } \\
\text { establish a policy to use only certified or sustainable } \\
\text { products } \\
\text { recommended by standard } \\
\text { Organisations? Does the organisation also register for } \\
\text { sustainable building Certification? }\end{array}$ \\
\hline $\begin{array}{l}\text { F2.6. Capital cost: What is the financial } \\
\text { preparedness of the organisation in terms of } \\
\text { capital investment? }\end{array}$ & $\begin{array}{l}\text { Does the organisation allocate } \\
\text { dedicated funds to support and } \\
\text { accelerate the adoption of offsite } \\
\text { construction techniques? }\end{array}$ & $\begin{array}{l}\text { If yes, does the organisation maintain a } \\
\text { financial strategy for future investments? }\end{array}$ & $\begin{array}{l}\text { Does the organisation establish a policy on investment } \\
\text { diversification and strategies? Also, does it critically } \\
\text { evaluate the business patterns and revise their investment } \\
\text { strategies? }\end{array}$ \\
\hline \multicolumn{4}{|l|}{ F3. Certainty in planning } \\
\hline $\begin{array}{l}\text { F3.1. Cost certainty: To what extent does the } \\
\text { organisation plan and monitor the budget } \\
\text { performance? }\end{array}$ & $\begin{array}{l}\text { Does the organisation document the } \\
\text { estimates at the beginning of the } \\
\text { project? Also, is there any evidence } \\
\text { of integration between project } \\
\text { administration and control? }\end{array}$ & $\begin{array}{l}\text { If yes, does the organisation closely } \\
\text { monitor the project expenses and compare } \\
\text { with the estimates? Also, does it take } \\
\text { measures to avoid any variation? }\end{array}$ & $\begin{array}{l}\text { Does the organisation implement a standardised project } \\
\text { in financial accounting and management systems? }\end{array}$ \\
\hline $\begin{array}{l}\text { F3.2. Time certainty: How does the } \\
\text { organisation plan critical activities? What is the } \\
\text { capability of the organisation to ensure that } \\
\text { there is no variation between the estimated and } \\
\text { actual completion date? }\end{array}$ & $\begin{array}{l}\text { Does the organisation identify critical } \\
\text { activities and follow their sequence of } \\
\text { execution? }\end{array}$ & $\begin{array}{l}\text { Does the organisation monitor and review } \\
\text { onsite activities and take precautions to } \\
\text { avoid any delay? }\end{array}$ & $\begin{array}{l}\text { Does the organisation establish a policy to optimise } \\
\text { performance through ensuring process standardisation? }\end{array}$ \\
\hline \multicolumn{4}{|l|}{ F4. Operational efficiency } \\
\hline $\begin{array}{l}\text { F4.1. Minimising onsite duration: What is the } \\
\text { capability of the organisation to reduce } \\
\text { /minimise the length of non-critical activities } \\
\text { during construction onsite? }\end{array}$ & $\begin{array}{l}\text { Does the organisation identify and } \\
\text { control/avoid non-critical activities } \\
\text { during the planning and onsite? }\end{array}$ & $\begin{array}{l}\text { Does the organisation efficiently plan and } \\
\text { execute all parallel activities during the } \\
\text { planning and onsite? }\end{array}$ & $\begin{array}{l}\text { Does the organisation ensure that all appropriate offsite } \\
\text { activities are completed before starting erection on } \\
\text { construction site? Also, does it standardise the onsite } \\
\text { working process? }\end{array}$ \\
\hline $\begin{array}{l}\text { F4.2. Prompt delivery: How does the } \\
\text { organisation ensure prompt delivery of products } \\
\text { and services? }\end{array}$ & $\begin{array}{l}\text { Does the organisation closely work } \\
\text { with supply chain and logistics } \\
\text { involved in various projects? }\end{array}$ & $\begin{array}{l}\text { Does the organisation collaborate with } \\
\text { select vendors and consultants involved in } \\
\text { various projects? }\end{array}$ & $\begin{array}{l}\text { Does the organisation maintain a directory of efficient } \\
\text { vendors and service providers based on their } \\
\text { performance? Is there a practice of partnering with } \\
\text { providers/vendors? }\end{array}$ \\
\hline
\end{tabular}


This paper uses the framework described and documented in Table 1., developed by Bendi et al., (2020) to present three case studies of large construction consultancies in India as the companies have a presence throughout India, which helped to understand the local challenges as well that are peculiar to certain areas only.

\section{Methodology}

To capture the OSC readiness, the framework previously described was applied to three case studies of large construction companies in India. A case study can be defined as a strategy to do research that involves an empirical investigation of a particular phenomenon within its real life context, primarily when the boundaries between phenomenon being studied and the context within which it is being studied are not clearly evident (Yin, 2013, 2018). This research method is especially useful in validating and testing the theoretical models by using them in real-life situations and organisations. Data collection was undertaken via semi-structured interviews providing a spectrum between the unstructured and structured extremes (Friedman, 2003; Fellows, 2009; Buchanan and Gardner, 2019). Interviews also help give a broader picture and more comprehensive details about the topic non-verbal communication such as body language has also impacted the answers.

For this research, several construction organisations were approached to practice OSC methods, of which three organisations (Companies A, B and C) agreed to participate in the study. Four people were interviewed from each company. During each case study, senior project managers, architects, HR managers and technical staff of the selected organisations were interviewed. All participants possessed more than five years of work experience in the field of OSC. Interviews took place in each employee's office, and every interview took between 45 minutes to one hour. All the participants were selected based on their position and experience in the field of OSC projects. In the first step, they were provided information about the research and explained the purpose of these case studies to all the participants. Furthermore, all the participants were interviewed about the level of maturity of each key factor and subfactor in their organisations. They were also provided with the printouts of Figure 1. and Table 1. 
Table 2 Interviewee Profiles

\begin{tabular}{|c|c|c|c|c|}
\hline No. & Position & Education & $\begin{array}{l}\text { Duration with } \\
\text { Company } \\
\text { (Years) }\end{array}$ & $\begin{array}{c}\text { Total Experience } \\
\text { (Years) }\end{array}$ \\
\hline \multicolumn{5}{|c|}{ Company $\mathrm{A}$} \\
\hline 1 & Senior Project Manager & Masters & 13 & 34 \\
\hline 2 & Architect & Bachelors & 5 & 8 \\
\hline 3 & HR Manager & Masters & 7 & 15 \\
\hline 4 & Design Engineer & Bachelors & 2 & 2 \\
\hline \multicolumn{5}{|c|}{ Company B } \\
\hline 1 & Project Manager & Masters & 12 & 30 \\
\hline 2 & Senior Design Engineer & Masters & 8 & 16 \\
\hline 3 & Procurement Manager & Masters & 5 & 11 \\
\hline 4 & Design Engineer & Bachelors & 3 & 5 \\
\hline \multicolumn{5}{|c|}{ Company $\mathrm{C}$} \\
\hline 1 & Senior Project Manager & $\mathrm{PhD}$ & 7 & 26 \\
\hline 2 & Senior Architect & Masters & 8 & 14 \\
\hline 3 & Civil Engineer & Bachelors & 3 & 7 \\
\hline 4 & Design Engineer & Bachelors & 4 & 5 \\
\hline
\end{tabular}

This was performed so that the respondents can put their thoughts in the context of the maturity model. Flexibility was given during the interviews to talk without the restriction of tough questions, order, or the checklists. It helped them to explain in detail the systems their companies have been using regarding OSC, IT systems, internal processes, procurement methods, market challenges and other relevant issues.

\section{Case Studies}

\section{Company A}

Company A was established in 1982; its specialisation areas are Engineering, design, construction, and procurement for urban infrastructure, industrial infrastructure, ports and terminals, roads, bridges, and metros. The company has a presence in several cities of India. During the interviews with the senior management at organisation A, it was realised that the company prioritises the staff training to minimise the issues caused by complex interfacing between off-site modules. There is a standard practice of providing training to every new employee in the first month of their job. Though the organisation has an established policy on training, they did not customise a standard procedure for OSC projects. Regarding the duties and taxes, the organisation predominantly uses locally available material and systems, and the management instructed the design and procurement teams to purchase all the material from local vendors. The senior project manager indicated that the finance division deals with all the project's purchase orders and finances.

Additionally, an HR manager said that the finance department maintains the paid and payable taxes. Concerning the level of experience, the HR manager reported that five of their current employees have more than seven years of experience working in the OSC area. There was also an indication that the management is keen to recruit OSC experienced employees and skilled 
workforce in the near future, as the organisation has a strategic approach to recruitment. Organisation A prioritised promotional activities in their strategy to promote the advantages of OSC. According to the participants, the organisation extensively participates in the annual exhibitions and the management conducts awareness programmes and lecturing sessions in the college of architecture. The organisation runs a fully equipped fabrication yard of 20,000 square meters and maintains good relations with various stakeholders, ensuring no delays to the activities on the critical path to assuring the best Lead times. All participants expressed significant resistance from some of the clients (Client resistance); however, this has reduced in recent years. The organisation religiously encourages all their clients to achieve excellence and competitive advantage by adopting modern construction methods. The strategy of the organisation emphasises innovation and application of modern techniques in construction and infrastructure development. Organisation A encourages all their clients to adopt OSC methods based on the relevancy of the projects. Management ensures that all the learning material and guidance charts are displayed in the site office and has established a learning practice for all the projects. Instructors and technical staff ensure that the entire workforce is aware of the working methods and installation procedure.

The senior project manager conveyed that the management is aware of the pre-requisites involved in the transportation of OSC products (transportation infrastructure). It extensively builds with local products and runs an in-house fabrication yard. The project design and engineering team explained that they finalise the product selection and prepare all the estimation documents at the project's early stages. In the last six years, the project manager also shared that the management has repeatedly awarded contracts to four vendors based on their effective and prompt delivery. All the interview participants expressed how the shortage of materials and services challenges the performance of the organisation. The organisation's fabrication yard is manufacturing round the clock to meet the demand. Organisation A procures locally manufactured products, and the architects stated that they receive standards and guidelines for a significant number of products. They strictly follow the guidelines during the design and execution stages.

It as noted that organisation A's management does not prioritise the usage of eco-friendly products; however, respondents were aware of the OSC eco-friendly features. Most of the participants were unaware of the organisation's capital investment, financial planning, the organisations emphasis of cost-effectiveness, and adding a competitive advantage to all its clients. The organisation's project planning team has effective coordination with the manufacturers and all other stakeholders of their projects. The management ensures critical planning of all projects; however, they are yet to customise a standard procedure for OSC projects. The project manager and the site-in-charge follow the procedures set in the companies procedure for project management. This includes organising weekly meetings from the inception to the handover stage, monitoring on-site construction activities, supply chain engagement, etc. Prompt delivery via the in-house fabrication yard ensures fast delivery of manufactured systems to the selected projects. In addition, the organisation also maintains collaborations with the supply chain and service providers. 
Table 3 Summary of results of Organisation A

\begin{tabular}{|c|c|}
\hline Factor & Organisation $\mathrm{A}$ \\
\hline \multicolumn{2}{|l|}{ F1. Operational challenges } \\
\hline $\begin{array}{l}\text { F1.1. Complex interfacing } \\
\text { between the systems }\end{array}$ & Level - 2 \\
\hline F1.2. Duties and taxes & Level - 2 \\
\hline $\begin{array}{l}\text { F1.3. Level of experience in Off- } \\
\text { Site Construction methods }\end{array}$ & Level - 1 \\
\hline $\begin{array}{l}\text { F1.4. Promoting the advantages } \\
\text { of Off-Site construction }\end{array}$ & Level - 3 \\
\hline F1.5. Lead times & Level - 3 \\
\hline $\begin{array}{l}\text { F1.6. Client resistance and } \\
\text { scepticism }\end{array}$ & Level - 2 \\
\hline F1.7. Guidance and information & Level - 3 \\
\hline \multicolumn{2}{|l|}{ F2. Broad execution strategy } \\
\hline \multirow{2}{*}{$\begin{array}{l}\text { F2.1. Transportation } \\
\text { F2.2. Manufacturing capacity }\end{array}$} & Level - 2 \\
\hline & Level - 3 \\
\hline F2.3. $\quad$ Shortage in local & Level - 1 \\
\hline $\begin{array}{l}\text { F2.4. Availability } \\
\text { codes/standards }\end{array}$ & Level -3 \\
\hline $\begin{array}{l}\text { F2.5. Maximising environmental } \\
\text { performance in the life cycle }\end{array}$ & Level - 1 \\
\hline F2.6. Capital cost & Level - 1 \\
\hline \multicolumn{2}{|l|}{ F3. Certainty in planning } \\
\hline F3.1. Cost certainty & Level - 2 \\
\hline F3.2. Time certainty & Level - 2 \\
\hline \multicolumn{2}{|l|}{ F4. Operational efficiency } \\
\hline F4.1. Minimising on-site duration & Level - 2 \\
\hline F4.2. Prompt delivery & Level - 3 \\
\hline
\end{tabular}

\section{Company B}

Organisation B was founded in 1938; it is considered one of India's largest engineering and construction companies. Their area of work includes construction, heavy equipment, electrical equipment, power, and shipbuilding. More than 84,000 people are employed in this organisation which makes it a reasonably large organisation. The organisation $\mathrm{B}$ has established a practice of conducting training sessions and workshops on-site before executing OSC products' usage. The organisation has recruited a skilled workforce to work on their 
current projects, where many OSC products are being used. Organisation B is committed to providing training and education on the application and complex nature of the OSC products, ultimately resulting in the successful adoption of OSC methods in their projects. According to the participants, the organisation usually considers the incurring duties and taxes on OSC products and general services during the procurement stage. However, they did not notice any change of product caused by the higher duties and taxes in their experience. Organisation B maintains a dedicated team for OSC projects and has a record of recruiting skilled designers and technicians for the OSC projects. The organisation participates in exhibitions; however, there were no dedicated efforts to promote the OSC methods, although they mentioned the advantages of OSC methods in their success stories.

During the interviews, a project manager expressed that the company religiously follows the vendors' dates and schedules during the project awarding stage; however, the organisation did not collaborate with any manufacturers of OSC systems. Thus, the organisation is at level two in the context of "Lead Times", which influences any organisation's OSC readiness. According to the project manager, the clients demanded usage of OSC systems in the OSC projects they have done up to this date, so it was more client-driven, and the client was vital in the decisionmaking process. Organisation B commonly briefs clients about modern methods and innovations in the construction sector and their relevancy to the project. The organisation religiously follows the workforce's training and up-skilling and has a dedicated Research and Development $(R \& D)$ department. The project planning team evaluates the existing road and other connecting networks of any potential site at the initial planning stage. In one of the previous projects (an international airport), they also requested that the manufacturers of OSC products submit on-site and off-site transportation and manoeuvring plans. The project planning and quantity surveyors team exchange the estimation and bill of the products of quantities with all the vendors before starting a project, the selection of materials is made during the project planning stage. The organisation maintains in-house facilities for form-work systems; however, management does not collaborate with other manufacturers. A procurement manager explained the difficulties they have faced during one of the OSC projects. According to his comments, the shortage of OSC systems in India has caused delays in projects; the organisation does not plan to address this risk. Manufacturers provide the design details and standards of the products and design and planning teams adhere to the standards.

Organisation B practices a standard method of recording the cost of each project. There is a central finance system which monitors the documentation of all the projects to ensure cost certainty. The organisation follows a project plan with all the critical activities in the required sequence, and the project team closely monitors the activities on-site and take measures to avoid confusion and delays. However, no standard policy is adopted for the planning of OSC project to ensure time certainty. The project planning team considers all non - critical activities during the planning stage. During the execution, they ensure that all parallel activities are being executed according to the plan on-site; however, according to the manager, this approach slightly varies from project to project depending on the project's nature/type. The organisation collaborates with selected vendors such as HVAC (Heating, Ventilation, and Air Conditioning) and electrical consultants. Furthermore, they also have in-house facilities of pre-cast slabs and 
maintain fabrication yards on-site. Thus, according to the senior manager, the organisation ensures prompt delivery of most services and products.

Table 4 Summary of results of Organisation B

\begin{tabular}{|c|c|}
\hline Factor & Organisation $\mathrm{B}$ \\
\hline \multicolumn{2}{|l|}{ F1. Operational challenges } \\
\hline $\begin{array}{l}\text { Fl.l. Complex interfacing between } \\
\text { the systems }\end{array}$ & Level - 3 \\
\hline F1.2. Duties and taxes & Level - 2 \\
\hline $\begin{array}{l}\text { F1.3. Level of experience in Off-Site } \\
\text { Construction methods }\end{array}$ & Level - 3 \\
\hline $\begin{array}{l}\text { F1.4. Promoting the advantages of } \\
\text { Off-Site construction techniques }\end{array}$ & Level - 1 \\
\hline F1.5. Lead times & Level - 2 \\
\hline $\begin{array}{l}\text { F1.6. Client resistance and } \\
\text { scepticism }\end{array}$ & Level -3 \\
\hline F1.7. Guidance and information & Level - 3 \\
\hline \multicolumn{2}{|l|}{ F2. Broad execution strategy } \\
\hline F2.1. Transportation infrastructure & Level - 3 \\
\hline F2.2. Manufacturing capacity & Level - 2 \\
\hline F2.3. Shortage in local availability & Level - 1 \\
\hline F2.4. Availability of codes/standards & Level - 2 \\
\hline $\begin{array}{l}\text { F2.5. Maximising environmental } \\
\text { performance in the life cycle }\end{array}$ & Level - 2 \\
\hline F2.6. Capital cost & Level - 1 \\
\hline \multicolumn{2}{|l|}{ F3. Certainty in planning } \\
\hline F3.1. Cost certainty & Level - 3 \\
\hline F3.2. Time certainty & Level - 2 \\
\hline \multicolumn{2}{|l|}{ F4. Operational efficiency } \\
\hline F4.1. Minimising on-site duration & Level - 2 \\
\hline F4.2. Prompt delivery & Level - 3 \\
\hline
\end{tabular}

\section{Company C}

Organisation C was founded in 1998; they offer engineering, design, construction and procurement services for various building and infrastructure projects. The organisation $\mathrm{C}$ 
conducts staff training and briefing sessions before executing work. There is no standard practice for regular training. In the previous projects, the staff encountered challenges in working with new systems. Training and guidance were introduced as an immediate response to addressing those challenges. Most of the participants avoided the question on "Duties and Taxes", with one of the interviewees saying that the project teams are unaware of them. In organisation $\mathrm{C}$, the procurement team identify the list of potential taxes on the OSC products and communicate this report to the finance division. It is understood that the organisation evaluates the legibility of duties and taxes on OSC products. The company is comprised of a combination of beginners in OSC and experienced staff in senior positions.

The design and project development team are dominated by professional staff who worked on more than two OSC projects. The construction workforce, however, had minimal knowledge of OSC products. The organisation did not conduct any promotional programmes to promote OSC methods. The management of the organisation publishes the success stories and awardwinning projects on the official website. The website promotes its name and reaches the targeted audience (stakeholders). Despite the success stories and award-winning projects, the organisation did not include promotion and awareness campaigning in their strategy. The project planning team always considers the manufacturers and suppliers' time frames while planning the activities sheet and time charts. The organisation maintains a close working relationship with all consultants and vendors. Vendors are set up on contracts for various projects, and the close engagement results in the on-time delivery of multiple products. Organisation C encourages its clients to adopt OSC methods and other new technologies; when initiating a new project, the consultants detail the client's initial meeting requirements. The engineering team evaluates the project brief and assesses the scope for OSC implementation and other modern methods. According to the architects, the resistance and scepticism from the clients are minimal. Organisation $\mathrm{C}$ provides guidance and information about OSC products to the design and engineering team. The architects stated that they have access to various information and literature regarding the new construction methods in the library; additionally, the management provides training to the entire workforce at the beginning of every OSC project. However, the organisation does not have any dedicated resources for such training sessions.

Participants suggested that they know the unique requirements involved in working with OSC products, but they have a minimum understanding of transportation planning and requirements in transporting OSC products. The procurement and logistics teams of the organisation C work closely with the suppliers and manufacturers, and the organisation maintains collaborations with some of the manufacturers and ensures that all the manufacturers abide by the terms of the contract. Organisation C currently does not have an in-house OSC offering, but the management is considering establishing three manufacturing facilities; additionally, the organisation has established affiliations and partnerships with international construction companies for technical consultation and knowledge exchange.

The responding architects reported that they received the standards and specifications at the design stage's initiation; the design head ensures that all the specifications are obeyed in all the projects; a similar procedure occurs in OSC projects. Project managers' monitoring ensures the 
successful application of these standards in the execution stage. The organisation is committed to spreading the green footprint, and sustainability is embedded in the organisation's vision document. The organisation $\mathrm{C}$ is continually deploying new energy-saving technologies in the operations and has also successfully commissioned a "LEED GOLD" certified facility, and a "LEED SILVER" accredited facility. The organisation is also planning to increase the utilisation of existing resources and extend the envelope by implementing new construction technologies.

Financial planning is exclusively dealt with by the finance division; thus, the project and design teams are unaware of the capital investment. The management has established a standard procedure in terms of cost planning and monitoring. The project manager explained that the organisation aimed to achieve cost-effectiveness and shared an example from one of their recent projects, where they completed the entire project under the agreed budget. In addition, organisation $\mathrm{C}$ follows a standard project finance management system for all the projects, and they apply the same method to the OSC projects. Lean construction practices were embedded within its policies, and there was an established practice of submitting a "pre-construction" report before starting construction.

The organisation also adopted a Modular Project Delivery (MPD) approach for OSC projects; to minimise the on-site duration, the management ensures that all the supply chain adheres to the agreed delivery schedules. The project management team effectively coordinates and ensures no deviation in executing all critical activities by continuously monitoring and incorporating any delayed activities into a fast-track project delivery schedule for successful and timely completion. The supply chain management team details the procurement specifications during the pre-construction phase, performing supplier assessments and audits, undertaking the management of contract awards, to reliable local and international vendors. According to the senior project manager, the organisation adopted this policy to achieve schedule optimisation. They also developed and led a Modular Construction Technologies tour to identify the best vendors in the industry. This reflects that the organisation standardised the selection and awarding procedure for the OSC projects. 
Table 5 Summary of results of Organisation C

\begin{tabular}{|c|c|}
\hline Factor & Organisation $\mathrm{C}$ \\
\hline \multicolumn{2}{|l|}{ F1. Operational challenges } \\
\hline $\begin{array}{l}\text { F1.1. Complex interfacing } \\
\text { between the systems }\end{array}$ & Level - 2 \\
\hline F1.2. Duties and taxes & Level - 2 \\
\hline $\begin{array}{l}\text { F1.3. Level of experience in Off- } \\
\text { Site Construction methods }\end{array}$ & Level - 2 \\
\hline $\begin{array}{l}\text { F1.4. Promoting the advantages } \\
\text { of Off-Site construction }\end{array}$ & Level - 2 \\
\hline F1.5. Lead times & Level - 3 \\
\hline $\begin{array}{l}\text { F1.6. Client resistance and } \\
\text { scepticism }\end{array}$ & Level - 3 \\
\hline F1.7. Guidance and information & Level - 2 \\
\hline \multicolumn{2}{|l|}{ F2. Broad execution strategy } \\
\hline Transportation & Level -1 \\
\hline F2.2. Manufacturing capacity & Level - 2 \\
\hline F2.3. Shortage in local & Level - 3 \\
\hline $\begin{array}{l}\text { F2.4. Availability of } \\
\text { codes/standards }\end{array}$ & Level - 2 \\
\hline $\begin{array}{l}\text { F2.5. Maximising environmental } \\
\text { performance in the life cycle }\end{array}$ & Level - 3 \\
\hline F2.6. Capital cost & Level - 1 \\
\hline \multicolumn{2}{|l|}{ F3. Certainty in planning } \\
\hline F3.1. Cost certainty & Level - 2 \\
\hline F3.2. Time certainty & Level - 3 \\
\hline \multicolumn{2}{|l|}{ F4. Operational efficiency } \\
\hline F4.1. Minimising on-site duration & Level - 3 \\
\hline F4.2. Prompt delivery & Level - 3 \\
\hline
\end{tabular}

\section{Discussion and Analysis}

The purpose of this research work was to present the validation of the Off-Site Construction readiness framework. Three case studies were analysed to validate the framework and test its applicability in practice. This task has been carried out on real life construction organisations of different scale with different objectives. The validation procedures were carried out using interviews, document analysis, and other observable pieces of evidence. All three organisations 
had used both OSC practices along with the traditional methods of construction. The three case studies demonstrated that the proposed OSC Readiness framework assessed the level of OSC readiness of the organisations. The results were presented in Table 6 and 7 below. Through the findings, it can be understood that OSC practices were evident in all three organisations.

Table 6 Summary of results obtained from the case studies

\begin{tabular}{|c|c|c|c|}
\hline Factor & Organisation A & Organisation B & Organisation $\mathrm{C}$ \\
\hline \multicolumn{4}{|l|}{ F1. Operational challenges } \\
\hline $\begin{array}{l}\text { F1.1. Complex interfacing between } \\
\text { the systems }\end{array}$ & Level - 2 & Level - 3 & Level - 2 \\
\hline F1.2. Duties and taxes & Level - 2 & Level - 2 & Level - 2 \\
\hline $\begin{array}{l}\text { F1.3. Level of experience in Off-Site } \\
\text { Construction methods }\end{array}$ & Level - 1 & Level - 3 & Level -2 \\
\hline $\begin{array}{l}\text { F1.4. Promoting the advantages of } \\
\text { Off-Site construction techniques }\end{array}$ & Level - 3 & Level - 1 & Level -2 \\
\hline F1.5. Lead times & Level - 3 & Level -2 & Level - 3 \\
\hline $\begin{array}{l}\text { F1.6. Client resistance and } \\
\text { scepticism }\end{array}$ & Level - 2 & Level - 3 & Level - 3 \\
\hline F1.7. Guidance and information & Level -3 & Level -3 & Level -2 \\
\hline \multicolumn{4}{|l|}{ F2. Broad execution strategy } \\
\hline F2.1. Transportation infrastructure & Level - 2 & Level - 3 & Level -1 \\
\hline F2.2. Manufacturing capacity & Level - 3 & Level -2 & Level - 2 \\
\hline F2.3. Shortage in local availability & Level - 1 & Level - 1 & Level - 3 \\
\hline F2.4. Availability of codes/standards & Level -3 & Level - 2 & Level - 2 \\
\hline $\begin{array}{l}\text { F2.5. Maximising environmental } \\
\text { performance in the life cycle }\end{array}$ & Level - 1 & Level - 2 & Level - 3 \\
\hline F2.6. Capital cost & Level - 1 & Level - 1 & Level - 1 \\
\hline \multicolumn{4}{|l|}{ F3. Certainty in planning } \\
\hline F3.1. Cost certainty & Level - 2 & Level -3 & Level -2 \\
\hline F3.2. Time certainty & Level - 2 & Level -2 & Level - 3 \\
\hline \multicolumn{4}{|l|}{ F4. Operational efficiency } \\
\hline F4.1. Minimising on-site duration & Level - 2 & Level - 2 & Level - 3 \\
\hline F4.2. Prompt delivery & Level - 3 & Level - 3 & Level - 3 \\
\hline
\end{tabular}


Table 7 Summary of current OSC readiness of the three organisations (case studies)

\begin{tabular}{|l|l|l|l|}
\hline Factor & Org. A & Org. B & Org. C \\
\hline F1. Operational challenges \\
\hline Level - 1 & 1 & 1 & 0 \\
\hline Level - 2 & 3 & 2 & 5 \\
\hline Level - 3 & 3 & 4 & 2 \\
\hline F2. Broad execution strategy \\
\begin{tabular}{|l|l|l|l|}
\hline Level - 1 & 3 & 2 & 2 \\
\hline Level - 2 & 1 & 3 & 2 \\
\hline Level - 3 & 2 & 1 & 2 \\
\hline F3. Certainty in planning & 0 & 0 \\
\hline Level - 1 & 0 & 1 & 1 \\
\hline Level - 2 & 2 & 1 & 1 \\
\hline Level - 3 & 0 & 0 & 0 \\
\hline F4. Operational efficiency & 1 & 0 \\
\hline Level - 1 & 0 & 1 & 2 \\
\hline Level - 2 & 1 & 1 & \\
\hline Level - 3 & 1 & 1 & \\
\hline
\end{tabular}
\end{tabular}

All three organisations have reached level two in terms of "Duties and taxes". Hence, it can be said that all the organisations have considered the maintenance of records and monitoring the tax and duty payments as part of the material procurement strategy. Import duties and taxes are one of the most significant barriers to the uptake of OSC; therefore, these organisations should look for domestic products or produce themselves where possible (Rahman, 2013). Organisation B had established a standard procedure in most of its operations. This reflected in the organisation's practice in working with complex OSC products, recruiting experienced workforce, addressing the clients' scepticism, and providing training sessions and guidance to the staff. On the other hand, the Organisation $0 \mathrm{C}$ had demonstrated the more frequent application of OSC requisites at the operational level. However, it is yet to establish a standard operating procedure to achieve optimum advantage from the OSC techniques. Kamar et al. (2009) stated that the design and illustration of products must be documented systematically to ensure process standardisation is achieved during installation and construction phases. The need for standardisation in design and project function was emphasised by several researchers (Gibb and Isack, 2003; Tam et al., 2007; Pan, Gibb and Dainty, 2008; Azman et al., 2010).

Results against the broad execution strategy have revealed exciting findings; all three organisations' representatives shared minimal to no knowledge about "capital cost". This could be due to the sensitive nature of the data related to cost and finance. Organisation A and C have 
established standard practices in two areas, while organisation B had attained level 3 in only one area, that is in transportation infrastructure. Transportation infrastructure is seen as a critical contributor in OSC uptake, and problems here can have serious consequences, especially for the smaller projects (BRE 2007; Zhang et al., 2018). Therefore, end-to-end transportation should be assessed during the project planning stage. The OSC readiness framework assessed the organisations in certainty planning and operational efficiency factors. It was evident that all three organisations have attained maturity beyond the first level. Organisation A had a straightforward practice of applying standardised cost and planning methods. However, it lacked a strategic approach in this area. On the other hand, Organisation $\mathrm{B}$ and Organisation $\mathrm{C}$ have achieved level 3 in cost certainty and time certainty, respectively. The organisation A needs to adopt a strategic approach to ensure cost certainty and planning because it is seen as a fundamental pre-requisite for both contractors and clients (Xiao and Proverbs, 2003).

Similarly, all the organisations have demonstrated precise application in both minimising onsite duration and prompt delivery. All three organisations have crossed level one and achieved level three maturity in performing fast delivery, showing that the organisations have embraced a strategic approach to apply standard procedure in delivery methods and performance. This framework provides a formal process to be used by construction organisations in India to assess their readiness before adopting the OSC method and asserts the scope for upgrading within an organisation's processes.

Organisation $\mathrm{A}$ and $\mathrm{C}$ have standardised practices in two areas of the "broad execution strategy". However, out of the three organisations, Organisation A is only at level one in more (3) areas. The three organisations' planning efficiency assessment revealed that organisation A had reached level two of the OSC readiness in both time planning and cost planning. All three organisations need to develop their capacity in the efficient execution strategy as the OSC can help reduce the $\mathrm{CO} 2$ emissions while also contributing to reduced waste outputs and fewer resource requirements. The environmental impact of construction activity needs to be carefully controlled, from landfill (Jaillon et al., 2009; Gong et al., 2019), through to transportation (Krug, 2013). All three organisations reached a level in Captial Cost which is usually one of the most significant barriers to OSC as it tends to require higher up-front costs for the purchase of materials at the beginning of a project (Mtech, 2009). Once this initial investment has been absorbed into organisational business models, organisations should look for other available opportunities and joint ventures to achieve the economies of scale (Arif et al., 2012). On the other hand, organisations $\mathrm{B}$ and $\mathrm{C}$ have achieved level three in cost certainty and time certainty. The OSC readiness framework was applied in all the three organisations to evaluate the operational efficiency. The findings demonstrated that all the organisations had achieved the third level of OSC readiness in "Prompt delivery". Besides, Organisation C has acquired all the three levels in both the sub-factors. 


\section{Conclusion}

Current research and literature on OSC do not adequately assess the OSC readiness of construction organisations in India. Successful implementation of OSC highly depends on the readiness of the organisation and the organisations have to aware of their current strengths and weaknesses. Previously, there was no formal method of assessment to evaluate OSC readiness of the company at an organisation level. Although there were several maturity models but they couldn't assist organisations to level up and enhance their OSC readiness and implementation. The appropriation of maturity levels provides clear guidance and direction into the practical stages and issues needed for construction entities to maximise their OSC engagement within the Indian market. This also provides suitable direction and measures for evaluating and benchmarking their processes (strategic and operational) against core phases. The corollary of which enables organisations to evaluate their OSC 'preparedness' or readiness for engaging in the OSC market. Therefore, exercising this research has helped to fill the gaps identified in the literature and the OSC section in India. Hence, an OSC readiness maturity model would be influential for the initial assessment of OSC preparedness of India's construction organisations. This maturity model will serve as a guide for OSC practitioners, policymakers and other key stakeholders involved in improving the construction industry's quality in any country with similar demographics and conditions. The present research has made a significant contribution to two aspects of current knowledge. The study primarily established a set of 4 key areas that need to be considered at the organisational level while implementing OSC. Secondly, the research developed the OSC readiness maturity model to assess the construction organisations' status of readiness in India. The research will add to the existing knowledge of OSC by mapping issues relevant to the construction industry in India.

\section{Acknowledgements}

The authors would like to personally thank all participants for their engagement, support and insight used in the development and assesment of this Offsite Construction Readiness Maturity Model.

\section{References}

Ahuja, V., Yang, J. and Shankar, R. (2009) 'Study of ICT adoption for building project management in the Indian construction industry', Automation in Construction. doi: 10.1016/j.autcon.2008.10.009.

Aldridge, G. et al. (2001) 'Methods for measuring the "unmeasurable": evaluating the benefits of pre-assembly and standardisation in construction', 17th Annual ARCOM Conference, 5-7 September 2001.

Arif, M. et al. (2010) 'Promoting green construction in India through industry-academia 
collaboration', Journal of Professional Issues in Engineering Education and Practice. doi: 10.1061/(ASCE)EI.1943-5541.0000019.

Arif, M. et al. (2012) 'State of offsite construction in India-Drivers and barriers', in Journal of Physics: Conference Series. doi: 10.1088/1742-6596/364/1/012109.

Arif, M. and Egbu, C. (2010) 'Making a case for offsite construction in China', Engineering, Construction and Architectural Management, 17(6), pp. 536-548. doi: 10.1108/09699981011090170.

Attar, M., Kang, K. and Sohaib, O. (2018) 'Knowledge sharing culture, intellectual capital and organisational performance', in Proceedings of the 22nd Pacific Asia Conference on Information Systems - Opportunities and Challenges for the Digitized Society: Are We Ready?, PACIS 2018.

Auti, A. and Skitmore, M. (2008) 'Construction Project Management in India', International Journal of Construction Management. doi: 10.1080/15623599.2008.10773116.

Azman, M. N. A. et al. (2010) 'The common approach in the off-site construction industry', Australian Journal of Basic and Applied Sciences.

Azman, M. N. A., Ahamad, M. S. S. and Wan Husin, W. M. . (2012) 'Comparative Study on Prefabrication Construction Process’, International Surveying Research Journal.

Badir, Y. F., Kadir, M. R. A. and Hashim, A. H. (2002) 'Industrialised building systems construction in Malaysia', Journal of Architectural Engineering. doi: 10.1061/(ASCE)10760431(2002)8:1(19).

Bendi, D. et al. (2020) 'Understanding off-site readiness in Indian construction organisations', Construction Innovation. doi: 10.1108/CI-02-2020-0016.

Blismas, N., Pasquire, C. and Gibb, A. (2006) 'Benefit evaluation for off-site production in construction', Construction Management and Economics. doi: 10.1080/01446190500184444.

Blismas, N. and Wakefield, R. (2008) 'Offsite manufacture in Australia: barriers and opportunities.', QUT Digital Repository. Available at: http://eprints.qut.edu.au/27182.

Blismas, N. and Wakefield, R. (2009) 'Drivers, constraints and the future of offsite manufacture in Australia', Construction Innovation, 9(1), pp. 72-83. doi: $10.1108 / 14714170910931552$.

Bowmaster, J. and Rankin, J. (2019) 'A Research Roadmap for Off-Site Construction: Automation and Robotics', Modular and Offsite Construction (MOC) Summit Proceedings. doi: 10.29173/mocs91.

Building Research Establishment (BRE) (2007) Modern methods of construction (MMC) in housing: Parts I-IV. Watford, U.K.

Buchanan, C. and Gardner, L. (2019) 'Metal 3D printing in construction: A review of methods, research, applications, opportunities and challenges', Engineering Structures. doi: 10.1016/j.engstruct.2018.11.045.

Building Research Establishment (BRE) (2007) Modern methods of construction (MMC) in housing: Parts I-IV. Watford, U.K. 
Cheng, H. (2016) 'India's New Strategy for Urban Development: Enabling the Formation of Core Competitiveness', in ICCREM 2016: BIM Application and Offsite Construction Proceedings of the 2016 International Conference on Construction and Real Estate Management. doi: 10.1061/9780784480274.142.

Deepthi, B. et al. (2020) 'An off-site construction readiness maturity model for the Indian construction sector', Construction Innovation. doi: 10.1108/CI-07-2020-0121.

Durdyev, S. and Ismail, S. (2019) 'Offsite Manufacturing in the Construction Industry for Productivity Improvement', EMJ - Engineering Management Journal. doi: 10.1080/10429247.2018.1522566.

Edialeyoung, B., Seidu, R. D. and Appiah-kubi, J. (2020) 'Modular Construction Innovation in the UK: The Case of Residential Buildings', Proceedings of the International Conference on Industrial Engineering and Operations Management, 2022, pp. 806-816.

Egbu, C. O. (2004) 'Managing knowledge and intellectual capital for improved organisational innovations in the construction industry: An examination of critical success factors', Engineering, Construction and Architectural Management. doi: 10.1108/09699980410558494.

El-Abidi, K. M. A. et al. (2019) 'Using Prefabricated Building to Address Housing Needs in Libya: A Study based on Local Expert Perspectives', Arabian Journal for Science and Engineering. doi: 10.1007/s13369-019-03997-2.

Fellows, R. (2009) 'Advanced Research Methods in the Built Environment', Construction Management and Economics. doi: 10.1080/01446190902896637.

Friedman, K. (2003) 'Theory construction in design research Criteria: Approaches, and methods', in Design Studies. doi: 10.1016/S0142-694X(03)00039-5.

Gan, X. et al. (2018) 'Barriers to the transition towards off-site construction in China: An Interpretive structural modelling approach', Journal of Cleaner Production. doi: 10.1016/j.jclepro.2018.06.184.

Gibb, A. G. F. (2001) 'Standardisation and pre-assembly- distinguishing myth from reality using case study research', Construction Management and Economics. doi: 10.1080/01446190010020435.

Gibb, A. G. F. and Isack, F. (2003) 'Re-engineering through pre-assembly: Client expectations and drivers', Building Research and Information. doi: 10.1080/09613210302000.

Gong, P. et al. (2019) 'Modeling constraints for the on-site assembly process of prefabrication housing production: A social network analysis', Sustainability (Switzerland). doi: $10.3390 /$ su11051387.

Goodier, C. and Gibb, A. (2007) 'Future opportunities for offsite in the UK', Construction Management and Economics. doi: 10.1080/01446190601071821.

Goodier and Gibb (2005) 'Barriers and Opportunities for Offsite in the UK', Abdul Samed Kazi, ed. Systematic Innovation in the Management of Project and Processes, 11th Joint CIB International Symposium, 13-16 June 2005, pp. 148-158.

Goulding, J., Nadim, W., et al. (2012) 'Construction industry offsite production: A virtual 
reality interactive training environment prototype', Advanced Engineering Informatics. doi: 10.1016/j.aei.2011.09.004.

Goulding, J., Rahimian, F. P., et al. (2012) 'Offsite Construction: Strategic Priorities for Shaping the Future Research Agenda', Architectoni.ca. doi: 10.5618/arch.2012.v1.n1.7.

Goulding, J. and Arif, M. (2013) Offsite Production and Manufacturing, CIB General Secretariat. Available at: https://site.cibworld.nl/dl/publications/pub_372.pdf.

Haas, C. and Fagerlund, W. (2002) 'Preliminary Research on Prefabrication, Preassembly, Modularisation, and Off-site Fabrication in Construction', A Report of Center for Construction Industry Studies The University of Texas at Austin.

Herr, C. M. and Fischer, T. (2019) 'BIM adoption across the Chinese AEC industries: An extended BIM adoption model', Journal of Computational Design and Engineering. doi: 10.1016/j.jcde.2018.06.001.

Jaillon, L., Poon, C. S. and Chiang, Y. H. (2009) 'Quantifying the waste reduction potential of using prefabrication in building construction in Hong Kong', Waste Management. Elsevier Ltd, 29(1), pp. 309-320. doi: 10.1016/j.wasman.2008.02.015.

Jha, K. N. and Devaya, M. N. (2008) 'Modelling the risks faced by Indian construction companies assessing international projects', Construction Management and Economics. doi: $10.1080 / 01446190801953281$.

Kamar, K. A. M., Alshawi, M. and Hamid, Z. A. (2009) 'Barriers To Industrialized Building System (IBS): The Case of Malaysia', in Built and Human Environment 9th International Postgraduate Research Conference (IPGCR 2009).

Keupp, M. M. and Gassmann, O. (2013) 'Resource constraints as triggers of radical innovation: Longitudinal evidence from the manufacturing sector', Research Policy. doi: 10.1016/j.respol.2013.04.006.

Krug, D. (2013) OFFSITE CONSTRUCTION: Sustainability Characteristics. Available at: https://www.buildoffsite.com/content/uploads/2015/03/BoS_offsiteconstruction_1307091.pdf (Accessed: 7 May 2019).

Luthra, S., Garg, D. and Haleem, A. (2016) 'The impacts of critical success factors for implementing green supply chain management towards sustainability: An empirical investigation of Indian automobile industry', Journal of Cleaner Production. doi: 10.1016/j.jclepro.2016.01.095.

Mensah, J. (2019) 'Sustainable development: Meaning, history, principles, pillars, and implications for human action: A literature review', Cogent Social Sciences. doi: 10.1080/23311886.2019.1653531.

Mtech Consult Limited (Mtech) (2009) Offsite and MMC in affordable housing. Shrewsbury, U.K.

Nadim, W. and Goulding, J. S. (2010) 'Offsite production in the UK: The way forward? A UK construction industry perspective', Construction Innovation. doi: $10.1108 / 14714171011037183$.

Nadim, W. and Goulding, J. S. (2011) 'Offsite production: A model for building down barriers 
A European construction industry perspective', Engineering, Construction and Architectural Management. doi: 10.1108/09699981111098702.

Naoum, S. G. and Egbu, C. (2016) 'Modern selection criteria for procurement methods in construction: A state-of-the-art literature review and a survey', International Journal of Managing Projects in Business. doi: 10.1108/IJMPB-09-2015-0094.

Navaratnam, S. et al. (2019) 'Performance review of prefabricated building systems and future research in Australia', Buildings. doi: 10.3390/buildings9020038.

Oughton, D. (2016) 'Construction Leadership Council Innovation Workstream (Buildings), Roadmap for Modern Methods of Construction (MMC)', Workshop Report Issue 1.0, (April). Available at: https://baumanlyons.co.uk/wp-content/uploads/2016/05/Roadmap-for-ModernMethods-of-Construction1.pdf.

Page, E., Briggs, R. and Tufarolo, J. (2004) 'Toward a family of maturity models for the simulation interconnection problem', Proceedings of the Simulation InteroperabilityWorkshop.

Pan, W., Gibb, A. F. and Dainty, A. R. J. (2007) 'Perspective of UK housebuilders on the use of offsite modern methods of construction', Construction Management and Economics. doi: $10.1080 / 01446190600827058$.

Pan, W., Gibb, A. G. . and Dainty, A. R. . (2008) 'Leading UK housebuilders' utilisation of offsite modern methods of construction', Building Research \& Information, 36(1). Available at: https://dspace.lboro.ac.uk/dspace-jspui/bitstream/2134/6181/1/Pan.pdf.

Rahman, M. M. (2013) 'Barriers of Implementing Modern Methods of Construction', Journal of Management in Engineering, 30(1), pp. 69-77. doi: 10.1061/(ASCE)me.19435479.0000173.

Scheyvens, R., Banks, G. and Hughes, E. (2016) 'The Private Sector and the SDGs: The Need to Move Beyond "Business as Usual", Sustainable Development. doi: 10.1002/sd.1623.

Shrivastava, S. and Chini, A. (2011) 'Construction Materials and C\&D Waste in India.', in Lifecycle Design of Buildings, Systems and Materials.

Smith, R. and Narayanamurthy, S. (2008) Prefabrication in Developing Countries: A Case Study of India.

Tam, V. W. Y. et al. (2007) 'Towards adoption of prefabrication in construction', Building and Environment. doi: 10.1016/j.buildenv.2006.10.003.

Tiwari, P. (2001) 'Energy efficiency and building construction in India', Building and Environment. doi: 10.1016/S0360-1323(00)00056-1.

Vyas, G. S. and Jha, K. N. (2016) 'Identification of green building attributes for the development of an assessment tool: a case study in India', Civil Engineering and Environmental Systems. doi: 10.1080/10286608.2016.1247832.

Wuni, I. Y., Shen, G. Q. and Hwang, B.-G. (2020) 'Risks of modular integrated construction: A review and future research directions', Frontiers of Engineering Management. doi: $10.1007 / \mathrm{s} 42524-019-0059-7$. 
Xiao, H. and Proverbs, D. G. (2003) 'Cost Certainty and Time Certainty: an International Investigation', Association of Researchers in Construction Management, 1(September), pp. 35. Available at: http://www.arcom.ac.uk/-docs/proceedings/ar2003-023032_Xiao_and_Proverbs.pdf.

Yang, L. R., O’Connor, J. T. and Chen, J. H. (2007) 'Assessment of automation and integration technology's impacts on project stakeholder success', Automation in Construction. doi: 10.1016/j.autcon.2006.11.005.

Yin, R. K. (2013) 'Applications of case study research', Applied Social Research Methods Series. doi: 10.1097/FCH.0b013e31822dda9e.

Yin, R. K. (2018) Case Study Research and Applications, Case Study Research and Applications: Design and Methods.

Yu, W. Der, Wu, C. M. and Lien, W. C. (2008) 'Fast innovation of construction technologies with computer-aided innovation tools', in ISARC 2008 - Proceedings from the 25th International Symposium on Automation and Robotics in Construction. doi: 10.3846/isarc.20080626.521.

Zhai, X., Reed, R. and Mills, A. (2014) 'Factors impeding the offsite production of housing construction in China: An investigation of current practise', Construction Management and Economics. doi: 10.1080/01446193.2013.787491.

Zhang, W. et al. (2018) 'The hindrance to using prefabrication in Hong Kong's building industry', Journal of Cleaner Production. doi: 10.1016/j.jclepro.2018.08.190. 